\title{
Análise fenômeno-estrutural de um caso de depressão utilizando desenhos: acompanhamento psicológico em ateliê de pintura e expressão
}

\author{
Andrés Eduardo Aguirre Antúnez ${ }^{1}$ \\ Klyus Vieira de Freitas ${ }^{2}$ \\ Jacqueline Santoantonio ${ }^{3}$ \\ Deise Matos do Amparo ${ }^{4}$ \\ Renata da Rocha Campos Franco ${ }^{5}$
}

\section{Resumo}

A análise fenômeno-estrutural possibilita compreender a evolução de uma paciente a partir da produção livre de desenhos e de suas verbalizações.

\begin{abstract}
${ }^{1}$ Doutor em Ciências da Saúde, Mestre em Saúde Mental e Especialista em Psicologia da Saúde pelo Departamento de Psiquiatria da Universidade Federal de São Paulo. Professor do Departamento de Psicologia Clínica do Instituto de Psicologia da Universidade de São Paulo IPUSP. Coordenador da pesquisa: Investigação do uso de procedimentos intermediários no atendimento clínico em grupo - Ateliê de Pintura de Livre Expressão, auxílio do CNPq - 20072009. Coordenador da Clínica Psicológica Prof. Durval Marcondes do IPUSP. Membro da Société Internationale de Psychopathologie Phénoméno-Structurale. Estágios no Centre Hospitaler Saint-Venant, Lillers e Université de Savoie, Chambéry, França. Email: antunez@usp.br
\end{abstract}

${ }^{2}$ Graduando em Psicologia do Instituto de Psicologia da Universidade de São Paulo, bolsista do Programa Institucional de Bolsas de Iniciação Científica e Iniciação Científica RUSP/CNPq/PIBIC, 2009 a 2010, com o projeto intitulado: À luz da empatia: estudo fenomenológico-clínico dentro de um ateliê de livre expressão terapêutica. Orientador: Prof. Gilberto Safra. Email: kvfsp@yahoo.com.br

${ }^{3}$ Doutora em Ciências da Saúde e Especialista em Psicologia da Saúde pelo Departamento de Psiquiatria e Psicologia Médica da Universidade Federal de São Paulo. Coordena o Ateliê de Pintura de Livre Expressão no Centro de Atenção Psicossocial - CAPS UNIFESP, Departamento de Psiquiatria, UNIFESP. Membro da Société Internationale de Psychopathologie Phénoménostructurale. Estágios no Centre Hospitaler Saint-Venant, Lillers e Université de Savoie, Chambéry, França. Email: jacqueline.santoantonio@uol.com.br

${ }^{4}$ Doutora em Psicologia Clínica pela Universidade de Brasília - Brasília - DF, com estágiosanduíche na Universidade Picardie Jules Verne-França e Pós-Doutorado na Universidade Paris V - França. Professora do Departamento de Psicologia Clínica e do Programa de Psicologia Clínica e Cultura da Universidade de Brasília. Bolsista Produtividade CNPq. Email: deiseamparo@unb.br

5 Doutora em Avaliação Psicológica pela Universidade São Francisco - Itatiba, com estágiosanduíche na universidade Picardie Jules Verne, França. Atua na área acadêmica, pesquisando e ministrando cursos ligadas as técnicas projetivas. Atualmente, desenvolve uma pesquisa de Pós-Doutorado "La psychopathologie phénoméno-structurale aplique aux problematiques toxicomaniaques", na França com financiamento da Fondation Maison des Sciences de l'Homme (boursiers Hermès). Email: fran_re@yahoo.com.br 
Acompanhamos uma pessoa adulta com depressão ao longo de três anos. Em atividade grupal, a paciente produziu desenhos que mostram preocupações e interesses com os detalhes, ritmo de produção lento, porém de modo cuidado e atento. As cores são presentes e suaves. Há pouca expressão de movimento, denotando predomínio da racionalidade sobre a sensorialidade. O sofrimento e o desamparo diminuíram e ela desenvolveu possibilidades associativas entre os acontecimentos depressivos e sua história de vida, o que não ocorria no início do tratamento. A paciente conquistou uma abertura em direção ao porvir, à alteridade e ao reconhecimento do outro. Dessa forma, a interlocução é central no método fenômeno-estrutural onde as evoluções são compreendidas pelo acesso à subjetividade compartilhada. Os mecanismos de ligação e corte se encontram não apenas nas estruturas epilépticas e esquizofrênicas, mas em qualquer estrutura humana, incluindo as vivências depressivas.

Palavras-chave: Análise Fenômeno-Estrutural; Desenhos; Depressão.

The phenomeno-structural approach applied in a case of depression by using drawings: a psychological follow up in a painting and self-expression workroom

\begin{abstract}
The phenomeno-structural approach enables the understanding of progress of a patient through spontaneous productions of drawings and the words followed therein. An adult subject with a history of three-year-depression was followed. In group activities, the patient produced drawings revealing concern for and interest in details, and a slow productive rhythm, though careful and attentive. The colours are present and soft. There is little expression of movement, denoting predominance of rationality over sensoriality. Suffering and abandonment decreased and the patient developed associative possibilities among the depressive events and her history of life, non-existent at the beginning of the treatment. The patient achieved an opening towards future, alterity and recognition of the other. Interlocution is thus vital in phenomenostructural approach from which progress is understood through the access to shared subjectivity.
\end{abstract}

Key-words: Phenomeno-Structural Approach; Drawings; Depression. 


\begin{abstract}
"A fenomenologia nos convida a nos determos sobre os fenômenos a fim de precisar os caracteres fundamentais. Antes de conhecer a origem, nós queremos saber o que são, quais são os elementos que aportam - cada um em sua especificidade - à estrutura geral da existência" (Minkowski, 1966, p. 456).
\end{abstract}

\title{
Introdução
}

Uma pessoa começa a apresentar dificuldades de relacionamento em seu trabalho. A mesma procura ajuda em um hospital universitário, é diagnosticada com depressão e transtorno de ansiedade generalizada. Encaminhada à Clínica Psicológica Durval Marcondes do IPUSP para realizar psicoterapia, não encontra vaga naquele momento, porém se interessa por uma pesquisa clínica: o Ateliê de Pintura de Livre Expressão - procedimento intermediário no acompanhamento psicológico em grupo.

O intuito é acompanhá-la durante dois anos, em atendimentos em grupo, durante uma hora e meia, para aproximar-se do seu modo de ser e de se expressar, conhecendo assim quem é e como reage a esta modalidade clínica ao longo do tempo e oferecendo um espaço de acolhimento a seu sofrimento.

O método usado é qualitativo, se refere a um estudo de caso de acordo com a análise fenômeno-estrutural associado ao trabalho clínico de atendimento em grupo. O primeiro busca conhecer, por meio da linguagem verbal e da expressão de imagens no desenho, os mecanismos essenciais da linguagem, sendo os principais o mecanismo de ligação e corte, bem como a vivência espacial e temporal e a qualidade do contato vital ou desvitalizado com a realidade; o segundo busca compreender a paciente a partir de seu idioma pessoal e da sua semântica peculiar. Assim, um método observa e revela o vivido, o outro implica uma ética no encontro humano, onde a solidariedade e amizade ontológicas são fundamentais no cuidado e acompanhamento de alguém.

Observamos que ao longo de três anos - um ano a mais da proposta inicial já que a paciente pediu para continuar participando do grupo após os dois primeiros anos - pode expressar, por meio dos desenhos e dos comentários em relação aos mesmos, facetas de sua história que jamais haviam sido 
dialogados com alguém. No início desenhava conteúdos da natureza e se impressionava porque ela não conseguia desenhar figuras humanas como as outras pessoas, mas com o tempo, alcançou essa possibilidade. Poder expressar suas vivências interiores permitiu que compreendesse seu próprio tempo e ritmo, sua biografia associada aos momentos atuais. Desenha com cores, formas muito bem definidas, contornos realizados cuidadosamente, se envolvendo na atividade.

Discutimos que ao compreendermos, em conversas semanais, as rupturas que se revelam nos desenhos tais como aparecem em sua vida, abriram-se possibilidades de crescimento e amadurecimento. Assim, após dois anos de trabalho, seus sintomas estavam em remissão, solicitando seu prosseguimento no Ateliê. A paciente está há seis meses sem uso de medicação e com acompanhamento psiquiátrico mais espaçado.

\section{O método de análise fenômeno-estrutural: a Linguagem, o Rorschach e os Desenhos}

A abordagem fenômeno-estrutural é apresentada em psicologia como tendo na análise do método de Rorschach seu instrumento principal. Embora não seja muito conhecida no Brasil, esta abordagem tem contribuições importantes a dar para a compreensão dos dados qualitativos que sobressaem da riqueza desse método (Jacquemin, 1998; Amparo \& Antúnez, 2008). A investigação psicológica é abordada no contexto do estudo clínico de caso, em que o particular pode trazer elementos do universal. A prevalência da observação e da descrição refinada revela elementos da linguagem e da subjetividade, compreendendo que a objetividade não pode se estabelecer em ausência da subjetividade que a ela concerne. Nesse contexto, segundo indicações do próprio Hermann Rorschach (1967), a perspectiva objetiva de pesquisa com o seu método ultrapassa a caracterização de indicadores psicométricos, pois valoriza a clínica nas implicações que todo contato com o outro no campo do humano solicita.

Os mecanismos de ligação (lien) e corte (coupure), respectivamente característicos dos quadros clínicos de epilépticos e esquizofrênicos, constituem a base da tipologia de Françoise Minkowska (1956), núcleo da noção de estrutura da psicopatologia fenômeno-estrutural, que se oferece como base para a explicação das relações indivíduo/mundo. A ligação que estrutura a atitude do sujeito no espaço e no tempo tende a manter juntas as partes separadas. Em detrimento do contorno formal que isola as figuras, o movimento é 
indissociável da ligação que dá unidade estrutural na epilepsia. Em contraste com a ausência de cinestesia, o esquizofrênico com frequência faz uso de termos como separado, partido e fragmentado, que possuem relação com o mecanismo essencial da esquizofrenia, a Spaltung. Sob a influência do trabalho de Minkowska, algumas pesquisas têm sido realizadas com o método de Rorschach, na abordagem fenômeno-estrutural, identificando a presença desse mecanismo nesse quadro clínico (Helman, 1984; Ternoy, 1998; Wawrzyniak, 1994, 1995; Samba, 1981; Santoantonio \& Antúnez, 2002; Amparo, 2002, 2004, 2010).

A apreensão dos modos fundamentais com uma unidade estrutural, com os mecanismos de corte e de ligação, interessa-nos, aqui, desde que Minkowska acrescenta à obra de Rorschach uma análise da linguagem, que é uma das grandes aquisições da psicopatologia fenômeno-estrutural.

É, também, um dado essencial a forma em que se desenvolve o teste em sua totalidade, ou seja, a sucessão das imagens. A perspectiva é observar o movimento de apreensão do mundo em suas formas mais do que o seu conteúdo. Trata-se de encontrar os princípios mais profundos de ordem estrutural que presidem a maneira de ver e colocar-se em contato com o real. Essa perspectiva de valorização das imagens como atos do espírito é consonante com a visão de Cassirer como apresenta Delauney (1975, p. 33): “as imagens são os atos do espírito".

Para chegar às imagens, Minkowska (1956) aconselha partir do caráter concreto e vivo dos fatos observados. No contexto da análise dos casos clínicos, a autora acrescenta que todas as particularidades, mesmo as mais negativas, correspondem e testemunham a mesma forma de ser, pois há certa lógica, uma certa coesão, uma lei. Essa coesão, mesmo na dissociação, essa lógica, mesmo no irracional, essa lei que deve ser apreendida na análise qualitativa, permite dar ao Rorschach um caráter estrutural: "a transposição em signos é necessária para a triagem das respostas, mas em seguida nos reenviamos à análise da linguagem que imprime às respostas um caráter estrutural"' (Minkowska, 1956, p. 130).

Segundo Helman (1983) a base teórica e filosófica dos estudos de Minkowski, que influencia diretamente a análise do método de Rorschach, alicerça-se sobre a psicopatologia de Bleuler e a filosofia de Bergson. Bleuler coloca em evidência os mecanismos essenciais da esquizofrenia, a Spaltung e o autismo e Minkowski mostra a sua unidade estrutural. Bergson opõe dois aspectos fundamentais, a intuição e a duração vivida ao pensamento discursivo e o tempo mensurável. Na esquizofrenia, a intuição daria lugar à inteligência discursiva e à duração vivida ao espaço lógico. 
A influência marcante de Bergson no pensamento de Minkowski é fundamental para o delineamento teórico da sua perspectiva psicopatológica. A obra, "Essais sur les donnes imédiates de la conscience", orienta o pensamento de Minkowski e reflete-se, por consequência, na análise que Minkowska realiza do método de Rorschach. A perda da intuição e da duração vivida, descritas como distúrbios essenciais característicos do contato vital com a realidade, estão presentes no esquizofrênico. Essa perda do contato vital com a realidade refletese nos mecanismos compensatórios como o racionalismo mórbido, caracterizando a atitude fundamental do indivíduo esquizofrênico. Minkowski descobre a relação temporalização - espacialização e a distorção de sua ligação na esquizofrenia, desvalorização do tempo, superestimação do espaço e espacialização do pensamento (Wawrzyniak, 2000).

Françoise Minkowska não se dirigia apenas ao Rorschach, mas também à análise dos desenhos de crianças epilépticas, aos estudos da obra do holandês Van Gogh na sua sensorialidade em comparação com a do pintor francês Seurat e sua racionalidade, como modos distintos de ser. Os desenhos estão intimamente relacionados ao Rorschach, no qual os borrões de tinta foram cuidadosamente trabalhados por Hermann Rorschach, cujo pai era pintor.

Considerando ainda outra vertente de pensamento que influencia a análise fenômeno-estrutural na sua concepção atual, encontramos a obra de Prinzhorn (1922/1984) que dá importância às produções dos pacientes, desenhos e pinturas, campo do imaginário e da expressão como fonte de estudo (Helman, 1998).

Ao defender uma integração entre a forma artística e as outras configurações perceptivas, Prinzhorn (1922/1984) afirma que é impossível estabelecer dois processos de Gestaltung diferentes, um físico- plástico, que tende à natureza, e um ídeo-plástico, que tende à representação, sendo que haveria na extremidade dessas duas um acordo entre forma e saber, entre ritmo e conceito. Este autor busca na dimensão estética uma aproximação para discutir a natureza da construção simbólica. Prinzhorn é um psiquiatra alemão que editou o livro Bildnerei der Geisteskranken, em 1922, traduzido e editado em francês, em 1984, sob o título Expressions de la folie. O centro da sua estética é a noção de Gestaltung, um termo que vem do alemão e pode ser traduzido por "forma em formação" ou "configuração". Observa-se, no entanto que, muitas vezes, na linguagem corrente, há um deslizamento semântico que a traduz por "forma", efetivando uma espécie de coisificação que anula a noção de processo geral e dinâmico.

Nessa discussão sobre a Gestaltung, Prinzhorn não busca discernir as diferenças entre os normais e os doentes mentais, mas ele tenta esclarecer "o 
que está implicado na fabricação de qualquer coisa", ou seja, no processo de criação (Oury, 1989).

Segundo Prinzhorn (1922/1984), a Gestaltung é uma junção de pulsões, um tipo de energia primitiva que apresenta suas raízes relacionadas à necessidade de expressão. Essas pulsões são nomeadas de: pulsão de jogo coloca em atividade; pulsão de ornamentação - enriquece o meio, resulta do ritmo dialético entre a figura, o motivo, e o fundo; a tendência a reproduzir (pulsão de imitação); a tendência a ordenar (pulsão de ordenação) - coloca no lugar as coisas, constrói; a necessidade de símbolos (pulsão de simbolização) faz ascender a matéria a um outro domínio; a necessidade de comunicar coloca em forma e permite a manifestação .

O funcionamento no conjunto dessas seis pulsões permite-nos compreender o que chamamos "estilo", no qual se deve levar em consideração a fabricação, a forma de fazer. Segundo Oury (1989), há uma espécie de homeomorfia entre o que é criado e a personalidade daquele que cria, o estilo é, ao mesmo tempo, o estilo da personalidade.

Esse campo torna-se fecundo para a análise fenômeno-estrutural, desde que valoriza o estudo da expressão, da linguagem, do grafismo e da obra de arte. A problemática da construção e da estrutura do imaginário coloca-se de forma mais clara como objeto de estudo da psicopatologia estrutural. A imagem, "raízes da realidade" como coloca Bachelard (1957/1998), torna-se objeto de estudo e de investigação a partir de materiais e símbolos concretos como pinturas e desenhos.

Outro grande pilar da análise fenômeno-estrutural é encontrado em Zéna Helman, seguidora de Françoise Minkowska e aluna de Henri Wallon. Ela foi uma das grandes pesquisadoras da análise fenômeno-estrutural na França, possibilitando a continuidade aos Cahier Françoise Minkowska e a criação da Société Internationale de Psychopathologie Phénoméno-Structurale. Zéna Helman tornou possível a riqueza das perspectivas psicopatológicas dessa corrente pelo cruzamento dos dados tipológicos, abertos pela psicopatologia estrutural, com os evolutivos, advindos da obra de Henri Wallon (Wawrzyniak, 1998).

Na construção da perspectiva evolutiva no delineamento do método de análise, a influência de Henri Wallon concebe que a pesquisa pressupõe a atenção ao detalhe concreto, às descrições minuciosas e ricas de significações em que a observação ocupa lugar central e o estudo de caso pressupõe uma visão unitária da pessoa (Helman, 1983).

Os estudos de Wallon $(1987,1978)$ foram aproximados da psicopatologia fenômeno-estrutural por Helman, que buscava definir noções como variação 
estrutural e ímpeto sensório motor, possibilitando desenvolvimentos posteriores e prolongamentos dos estudos de Minkowska sobre a hipótese de uma constituição psicobiológica e evolutiva. Em uma perspectiva tipológica, é das variações dos pólos de personalidade que emergirá a noção de fatores fundamentais da estrutura da personalidade (Wawrzyniak, 2000).

Helman reúne as contribuições de Minkowska e Wallon, buscando as convergências de fundo das duas contribuições. No campo da epilepsia, a descrição realizada pelos dois autores, ressaltando o papel do movimento e da visão concreta, além da adesividade e da perseveração como características desse tipo mental se estendem a uma discussão sobre os sujeitos normais. Minkowska (1956) opõe o tipo epilepto-sensorial ao esquizo-racional da psicopatologia da esquizofrenia e Wallon (1978) reaproxima o tipo motor dos seus estudos sobre a epilepsia de um estado de desenvolvimento da criança, etapa concreta em que o pensamento é indivisível da ação que precede o desenvolvimento dos sistemas de representações, de que se servirá mais tarde o pensamento abstrato.

A abertura desse campo leva a uma importante fonte de estudos sobre o ímpeto sensório-motor com Helman desenvolvendo a noção de variação estrutural. Suas pesquisas desenvolvidas a partir de 1949, com a eletroencefalografia, a psicologia da criança e os tratamentos biológicos, introduziram na psicopatologia estrutural uma dimensão biológica e evolutiva. Estes estudos buscaram colocar em evidência as variações estruturais da personalidade em certas condições psicobiológicas ligadas com o curso da doença, seu tratamento e evolução. Descobriu-se um importante processo evolutivo, o ímpeto sensório-motor, que permitiu aprofundar certas nuances psicológicas por que passa a visão em imagens.

\section{Resgatando as possibilidades de comunicação a partir dos desenhos}

Sabe-se que os desenhos e as pinturas têm sido utilizados como meio de comunicação desde a Idade da Pedra. Os desenhos feitos nas cavernas contavam os costumes, as caçadas, as relações do grupo e as crenças de nossos ancestrais. Parte da história da civilização humana foi contada pela análise da expressão artística desses desenhos.

De materiais obtidos na natureza até os desenvolvidos pela tecnologia gráfica, o objetivo sempre foi o mesmo: registrar a percepção humana e 
transmiti-la ao mundo, criando marcas que reproduzem o sentimento e o pensamento do criador.

O interesse pela criação relacionando a arte com a saúde mental não é algo novo e já no século XIX apareceram as primeiras referências sobre o assunto, procurando compreender o pensamento e as emoções através do gesto criativo.

Ferraz (1998) faz uma bela revisão de literatura sobre o tema e constata que em 1872, Ambroise Tardieu foi um dos primeiros a estudar a relação entre os desenhos e os diagnósticos, sendo seguido por uma série de autores como Fritz Mohr, quem em 1906 observou nos desenhos de seus pacientes a existência de dissociações mentais nas construções fragmentadas, de condensações, de estereotipias e de perseverações. No início do século XX aparecem as primeiras aproximações entre as obras dos pacientes e os desenhos infantis relacionadas a processos regressivos presentes nos esquizofrênicos, referido por Eugen Bleuler.

De acordo com as pesquisas de Ferraz (1998), foi o médico Marcel Réja (1907) quem iniciou uma nova forma de analisar a arte dos pacientes com transtornos mentais, procurando compreender a natureza da criação como formas mais ou menos embrionárias de arte, associando à possibilidade criativa dos pacientes uma nova leitura; porém, dois autores foram decisivos no reconhecimento de que a criação do paciente era verdadeiramente uma produção artística: Walter Morgenthaler e Hans Prinzhorn.

Em 1921, Morgenthaler criou uma grande polêmica ao publicar seu estudo sobre as obras de arte de Adolf Wölfli (1864-1930), dando um novo enfoque estético sobre a arte do paciente com transtorno mental. Prinzhorn (1922/1984) procurou analisar os processos de criação artística dos pacientes verificando os mecanismos de elaboração que se evidenciam nas produções, observando como emerge o impulso criador e como se concretiza a produção artística da humanidade, o que mostrou que o paciente poderia ter possibilidades criadoras mesmo diante de problemas graves em sua saúde mental.

Poderíamos descrever detalhadamente a inter-relação entre a arte e o transtorno mental, mas outros autores já fizeram de maneira primorosa esse levantamento. Queremos, ao invés disso, compreender como esta modalidade de atendimento em grupo pode auxiliar pessoas com grave sofrimento psíquico, ao compartilhar o que foi criado, dando reconhecimento aos seus gestos motores e verbais, no sentido dado por Ternoy (1999a), de que ser é fazer e dar significado ao que foi feito. 
A expressão por meio do traçado do desenho é uma das primeiras descobertas da infância. Através dos desenhos, as crianças vão se apropriando da possibilidade de reproduzir o mundo interno e externo. $\mathrm{O}$ ambiente, por sua vez, é responsável por muito da compreensão do traçado em significados, em sentidos e em associações, e essa mudança é decisiva para o desenvolvimento do ser humano.

Segundo Pablo Picasso (1937) o desenho não é um jogo. Ele refere que é muito misterioso o fato de que o traço possa representar um ser vivo. Não somente sua imagem, mas, sobretudo, aquilo que ele realmente é. Mas, além de revelar ao outro os aspectos internos de quem desenha, ele apresenta ao próprio autor muitas respostas e potenciais de desenvolvimento. Assim, muitas instituições que oferecem tratamento psiquiátrico e psicológico têm adotado a expressão por meio do desenho de uma maneira terapêutica (Santoantonio \& Antúnez, 2002).

A pintura e o desenho como possibilidades de expressão correspondem a uma ação humana mais complexa que um simples traço sem importância Van Gogh (1853-1890) questiona e responde de modo profundo a importância de desenhar;

O que é desenhar? Como o conseguimos? É a ação de abrir-se um caminho através de um muro de ferro invisível, que parece encontrar-se entre o que sentimos e o que podemos. Como atravessar este muro, já que de nada serve golpeá-lo com força? Devemos minar este muro e atravessá-lo à base de lima e, no meu entender, lentamente e com paciência. E é assim que podemos continuar assíduos neste trabalho sem nos distrairmos, a menos que não poderemos e não arranjemos nossas vidas segundo nossos princípios. E isto vale tanto para as coisas artísticas quanto para as outras. (Van Gogh, 2010, p.91)

Minkowska foi a primeira a analisar a pintura de Van Gogh na perspectiva fenomenológica e apresentou seu estudo no primeiro congresso mundial de psiquiatria realizado em Paris em 1949. Ela observava seu traçado, os movimentos, o uso do espaço, as ligações e as relações com a psicopatologia da epilepsia nas crianças.

No primeiro livro publicado por psicólogos no Brasil sobre a "Psicopatologia fenômeno-estrutural", Villemor-Amaral e Yazigi (2010, p. 19) afirmam:

É famoso o estudo de Minkowska (1949) sobre os pintores Van Gogh, epiléptico, e Seurat, esquizo-racional, em que, contrapondo- 
os, coloca à luz as características dos dois tipos de estrutura mental nas manifestações plásticas. No polo epilepto-sensorial, o movimento dá vitalidade às formas, a cor tem tom afetivo, os objetos se tocam, linhas sobem e descem, os traços são lançados em formas de hachuras. Já no polo esquizo-racional, predomina a imobilidade, a precisão geométrica, a preponderância da forma sobre o movimento, a cor pobre ou inadequada, os objetos separados, isolados ou fragmentados (Helman, 1959).

Para Ternoy (1999a), ao analisar as obras a partir da fenomenologia, não se trata de buscar possibilidades de associação entre produção psicopatológica e inspirações ou criações artísticas ou mesmo retornar a questões acerca das ligações entre loucura e genialidade. Tomando-se cuidado para não cair em análises psicopatológicas reducionistas das obras de artes, esse é um caminho detentor de ensinamentos insubstituíveis graças ao poder expressivo do criador. Ternoy comenta que é certo que a loucura não cria o artista, mas o encontro de uma e de outra é possível e não poderia ser concebido sem marcas.

\section{Expressão gráfica no estudo fenômeno-estrutural}

O Ateliê de Pintura de Livre Expressão (Ternoy, 1997) é baseado na observação participante e ativa como procedimento terapêutico no tratamento de pacientes com transtornos psiquiátricos graves. Não se trata de oferecer ao paciente uma simples distração ou ocupação ou mesmo a produção de arte como meio terapêutico com um objetivo artístico ou catártico. $\mathrm{O}$ intuito não é que o paciente produza uma grande obra, mas o foco está na expressão compreendida como ato e movimento criativo.

O método fenômeno-estrutural permite uma aproximação distinta e peculiar ao sofrimento vivido, possibilitando ações terapêuticas próximas aos fenômenos tais como aparecem em cada paciente. É possível observar na livre expressão: os gestos, as necessidades, as dificuldades, as evoluções e os interesses, as ressonâncias, a empatia ou a ausência dela, os mecanismos essenciais de ligação e ruptura quando comparados ao Rorschach, nos desenhos e na linguagem verbal. As intervenções visam a aproximar-se ao que é próprio de cada indivíduo por meio da espera atenta e silenciosa até que um diálogo se inicie.

O método se apoia na análise do fenômeno buscando precisar suas características fundamentais. A importância de uma reflexão fenomenológica 
no campo da expressão possibilita entrar em contato com o outro e então observar sua visão de mundo. Ternoy $(1997,1999 b)$ refere que o estudo da linguagem dos pacientes psicóticos abre uma via de acesso à compreensão dos fenômenos fundamentais tanto em uma dimensão expressiva como relacional. A expressão é uma relação fundamental, particularmente dinâmica e viva. A expressão exteriorizada é endereçada sempre a alguém e postula, nem que seja virtualmente, um espectador, um interlocutor, susceptível de apreender aquele que se expressa. Ela revela a coexistência, a troca e a interação ou a ausência disso.

Dessa forma, a expressão no Ateliê, não se reduz à coisa realizada, mas a forma de expressão de quem cria. Para tanto o conteúdo da representação é tão importante como o próprio ato criativo. A expressão é compreendida em seu movimento constitutivo e dinâmico e é através da criação que a pessoa existe, se realiza e pode vir a ser (Ternoy, 1987).

O Ateliê de Pintura de Livre Expressão (Santoantonio \& Antúnez, 2010) é uma modalidade de atendimento em grupo que utiliza o desenho como expressão, compreendido em seu movimento constitutivo e dinâmico. A técnica busca favorecer o ato criativo compartilhado em momentos de silêncio e concentração e transita rumo à verbalização e o compartilhar das experiências vividas. A análise fenômeno-estrutural investiga os fenômenos essenciais que animam ou não a estrutura da personalidade, a saber, quais os mecanismos que predominam: de ligação ou de corte.

A observação de casos segundo a psicopatologia fenômeno-estrutural acompanha as pesquisas nesse método. Um caso é ao mesmo tempo fonte de inspiração e experimentação das noções, de modo que a observação tem nesta corrente um lugar primordial. A partir dos casos individuais, são estudados os problemas mais gerais. A psicopatologia fenômeno-estrutural encontra nos desenhos e, principalmente no Rorschach, um método rico que recorre à expressão e à estrutura, que pode relacionar o modo de visão, a linguagem e o comportamento (Helman, 1997).

De acordo com Barthélèmy (1997), a análise fenômeno-estrutural encontra seu lugar entre a psiquiatria e a psicanálise: ela não se atém ao conteúdo, mas dirige-se à forma, apreendida em sua mobilidade e dinamismo vivo; não usa o conceito de inconsciente, mas encontra no consciente as forças criativas que se afirmam por elas mesmas; e não recorre a interpretações com auxílio de simbolizações, mas na vida e na riqueza e força expressiva da linguagem. 


\section{Estudo de caso}

A depressão é um quadro bem conhecido na população e é considerado um transtorno que gera grande sofrimento. $\mathrm{O}$ tratamento costuma associar a intervenção medicamentosa e a psicoterapia. Nosso intuito não é nos aprofundarmos na descrição sintomatológica na qual se baseia a maioria dos estudos atuais, já que sabemos que o paciente, mesmo sem saber muitas vezes o nome do que sente, não se vê realmente compreendido em sua existência e subjetividade com a simples explicação diagnóstica. Queremos nos aproximar da pessoa que sofre a dor de uma tristeza que permanece, da falta de ânimo e vitalidade em sua vida como um todo, da falta de sentido no que faz no seu diaa-dia, não apenas nas evidências comportamentais. Como proporcionar o verdadeiro encontro com aquele que se vê aprisionado em seu sofrimento é o objetivo principal da apresentação desse estudo de caso.

De acordo com Barthélémy (2006), o que importa na aproximação fenômeno-estrutural em psicopatologia é, mais do que o estudo de inumeráveis casos, a compreensão intuitiva e profunda de alguns casos particulares. Assim, nos interessa conhecer como uma senhora vive as dificuldades que a afetam, como as descreve e como vive suas experiências, mais do que a depressão, mas a sua própria vida.

Esse trabalho é o prosseguimento de um estudo anterior (Antúnez \& Santoantonio, 2010) no qual utilizamos uma breve análise da linguagem de algumas pranchas do método de Rorschach e do teste de apercepção temática, bem como o resultado de uma prova de inteligência em três momentos distintos, antes de iniciar o Ateliê, após um e dois anos. Seguimos a apresentação de alguns desenhos selecionados pela importância que têm na evolução dessa paciente.

Este estudo de caso foi aprovado pelo Comitê de Ética em Pesquisa com Seres Humanos no IPUSP em 04/12/2006 e recebeu apoio do CNPq, processo número 400163/2007-1.

\section{Resultados e Discussão}

No primeiro ano de trabalho a paciente desenhava árvores grandes, com galhos cortados, nos quais nasciam pequenas folhas. A natureza sempre se apresentou como sendo de grande interesse. Seus traços finos, bem delimitados, 
mostram formas preenchidas por muitas cores. Chamava atenção o modo calmo ou até vagaroso que fazia seus desenhos. Os outros componentes do grupo já haviam terminado e ela continuava desenhando, não conseguia terminar na média temporal do grupo.

No primeiro tempo do Ateliê, aquele em que todos desenham, estabelecia-se um silêncio. Este silêncio lhe era muito desconfortante. A paciente perguntava por que ninguém falava nada, todos continuavam em silêncio. Após dois anos, ela mesma já tolerava bem trabalhar dessa forma sem se incomodar tanto. No terceiro ano, ela já experimenta permanecer em silêncio, o que para ela é uma vitória.

No segundo momento do Ateliê, quando se conversa sobre a produção de imagens, a paciente mostra muita capacidade de simbolização, ou seja, seus desenhos sempre representam algo de que ela necessita ou deseja falar. Ao olhar os outros desenhos ela se perguntava o motivo de não conseguir desenhar figuras humanas, porém, com o passar dos anos, ela começou a desenhar anjos e depois, pessoas. Mas não qualquer pessoa: ela começou a se representar no desenho!

Na perspectiva do Ateliê de Pintura de Livre Expressão (Santoantonio \& Antúnez, 2010), não interpretamos os desenhos sem a presença do seu criador, o que nos interessa é a revelação da paciente do que motivou seu desenho, de modo que desvela o segredo que a imagem guarda. Qualquer interpretação fora desse contexto seria pura manifestação da percepção do observador, não do paciente. Apresentaremos a seguir alguns desenhos com a verbalização da paciente:

\section{Desenho do muro com a frase: Eu mereço ser feliz}

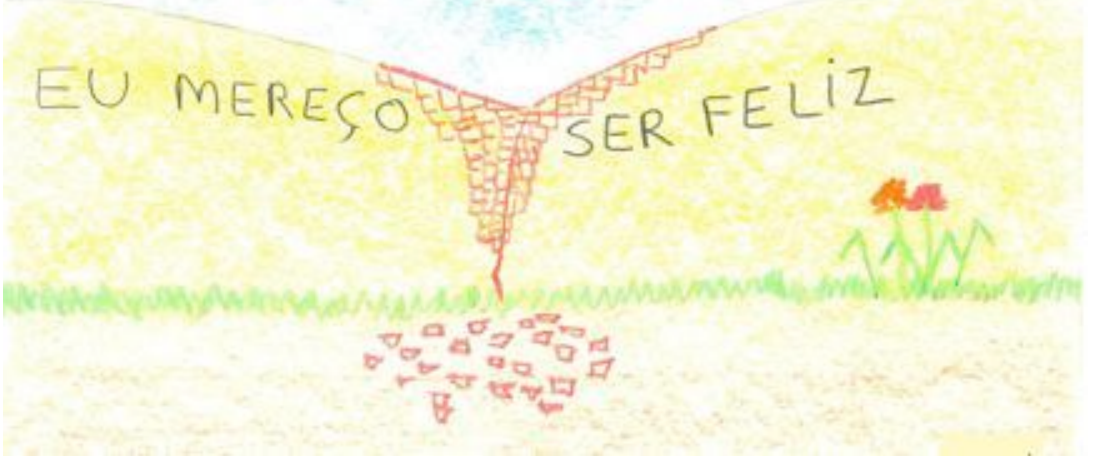


"Esse muro é a minha vida. Minha mãe dizia e diz que a nossa família veio para sofrer... Mas eu não quero acreditar nisso. E eu tenho sentido que eu também mereço ser feliz, mesmo com os problemas e dificuldades do dia-a-dia. Com a sua ajuda Andrés e com esse nosso grupo, eu estou conseguindo derrubar esse muro aos poucos, para ver o que tem do outro lado e esse muro também é a vida, e eu creio que do outro lado desse muro devem ter coisas boas".

2. Desenho do muro com as frases: Você é uma peste igual ao seu pai... Eu preferiria que você tivesse um câncer... Nenhum homem presta... É melhor nem tentar... Você só atrapalha... A nossa família veio pra sofrer...

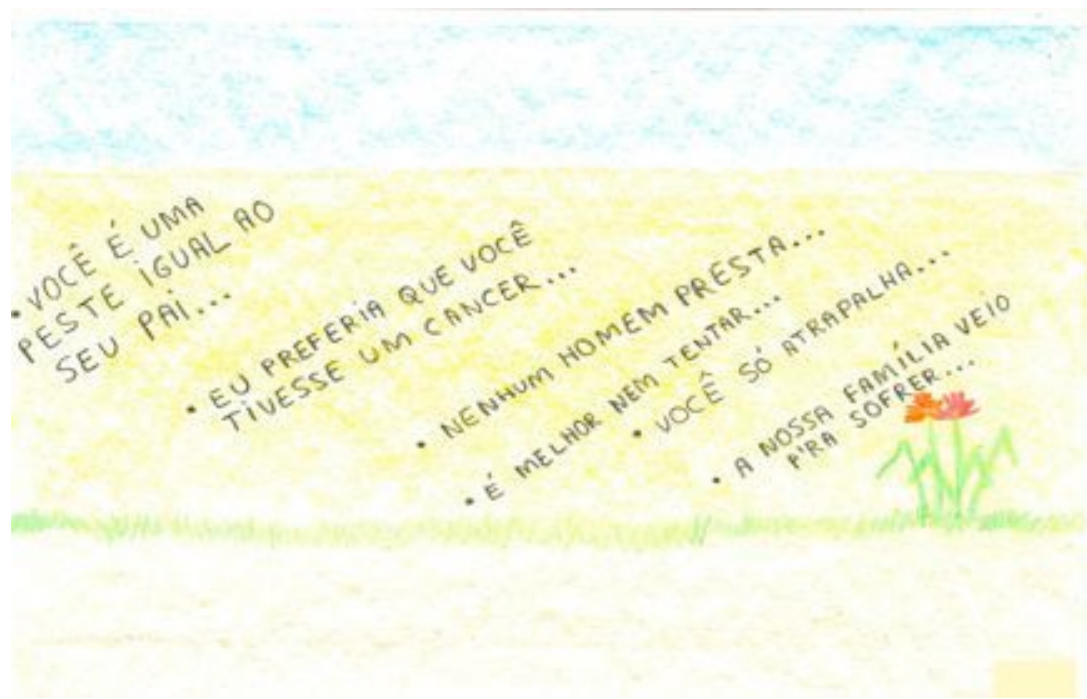

"Nesse muro eu escrevi frases que eu ouvi e ouço da minha mãe desde quando eu era pequena. Como essas frases me fizeram e me fazem mal. É por isso que muitas vezes eu sinto medo de tentar fazer alguma coisa, acho que não vou conseguir. Eu nunca vi o meu pai. Quando eu era pequena e minha mãe estava nervosa e dizia que eu era uma peste igual ao meu pai, hoje eu penso: se eu era igual ao meu pai, ele não deve ser tão ruim, pois eu também tenho coisas boas em mim... Na frase sobre o câncer, eu a ouvi quando eu the disse que estava grávida".

Os dois primeiros desenhos "muro com frases" são de representações gráficas que assumem a mesma função da folha de papel em branco: o muro é o pano de fundo para expor e registrar um pensamento que é carregado de sofrimento. Por intermédio de palavras a paciente revela valores emocionais externos que perturbam o seu equilíbrio. 
A expressão concreta das palavras pichadas no muro registra o desconforto interno atual e um desejo atemporal de conforto interno que é entendido pela paciente como felicidade.

Nesses desenhos (1 e 2), a paciente apresenta certa confusão sobre a sua auto-percepção. A imagem que ela faz dela mesma é contaminada pela imagem de sua mãe. Em especial, no segundo desenho, observa-se o registro de uma mãe vilã e culpada pelo destino da filha.

Nos diálogos em grupo ela pode ir aos poucos se discriminando das falas de sua mãe que permaneceram em sua memória. A paciente nunca havia conversado essas questões com alguém e, no grupo, encontrou um espaço de interlocução e acolhimento. Com o passar do tempo, tanto as imagens e os sofrimentos que carregava puderam ser expressos ao seu próprio ritmo. Essa possibilidade revelou a importância e força das reflexões, que uma vez compartilhadas, promovem novos sentidos para si.

O mecanismo de corte aparece na imagem do primeiro desenho, na cisão do muro que separa e protege, bem como nos estilhaços no chão. Apesar da dureza do muro e da vida, a paciente não a considera como sendo apenas investida de sofrimento, ou seja, ela diz "nossa família veio para sofrer... Mas eu não quero acreditar nisso. E eu tenho sentido que eu também mereço ser feliz". Há sempre uma força que palpita em sua personalidade, não há apenas sofrimento, mas há também a felicidade, o prazer, a satisfação. Ao mencionar ao terapeuta: "com a sua ajuda (...) eu estou conseguindo derrubar esse muro...", verificamos como a "ajuda" - mecanismo de ligação - permite que ela possa "derrubar" mecanismo de corte - barreiras que não permitiram que ela pudesse viver outras faces da existência. Sua linguagem verbal mostra que tais mecanismos (ligação e corte) coexistem e se alternam, se aproximando da possibilidade de integração.

O segundo desenho mostra a importância de um grupo de trabalho, cujo objetivo terapêutico é mais amplo que apenas observar desenhos e as verbalizações, mas sim se colocar em disponibilidade para ser usado como o paciente assim possa. Expressar vivências que estavam aprisionadas em seu ser mais íntimo permite mais que uma descarga, visão reducionista, mas um colocar em movimento seus traumas. Um mês após a realização desse desenho ela comenta que ficou pensando sobre essas coisas e percebeu que sua mãe foi realmente dura com ela e com seu pai. Ao falar sobre o desenho se remete ao pai e consegue questionar o que a própria mãe lhe dizia, pois ela se colocava no lugar dele, ao pensar de si mesma "se eu era igual ao meu pai, ele não deve ser tão ruim, pois eu também tenho coisas boas em mim...". Assim, ela percebe que não é apenas habitada pelo "ruim", mas também pelas "coisas boas". A frase "sobre o 
câncer, eu a ouvi quando eu the disse que estava grávida" traz uma carga dramática impressionante, quando ela revela à sua mãe sobre sua gravidez, sobre a vida que carrega dentro de si, a mãe lhe diz que "preferia que você tivesse um câncer", "câncer" poderia estar agindo aqui como uma cisão com a própria vida. Ao conversarmos sobre esses assuntos, um mês depois, é a capacidade de perdoar o que nos chama atenção, possibilidade conquistada na alteridade.

3. Desenho com vários sacos de lixo, materiais de limpeza, vassouras, rodo e uma janela com uma planta e um gatinho:

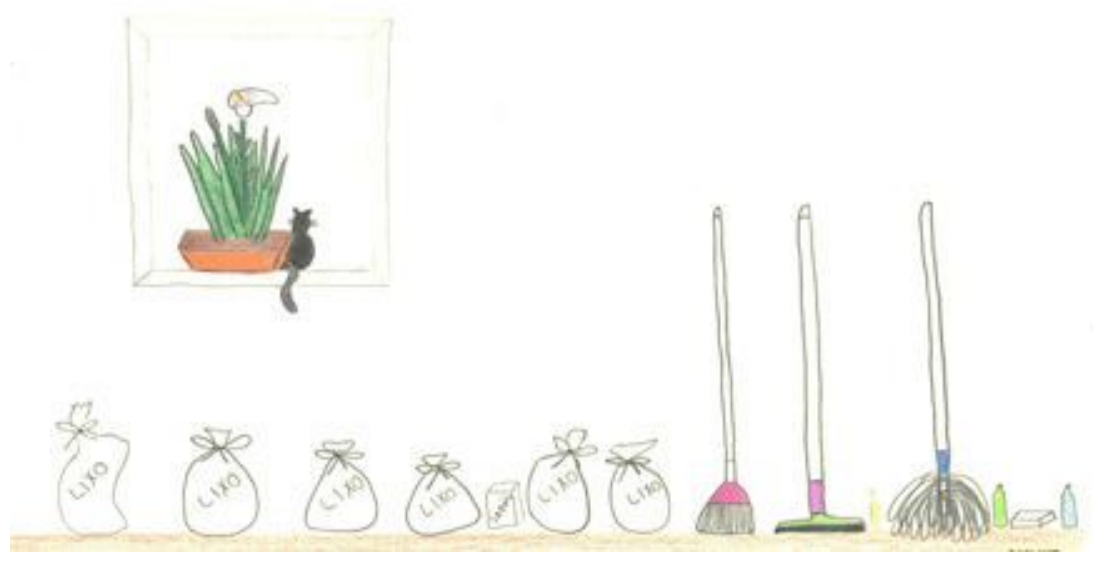

"Eu estou tentando arrumar minhas coisas, o meu quarto. Consegui limpá-lo e joguei muitas coisas que não serviam. Aquele vaso é uma flor que eu tenho, e essa flor abre e no mesmo dia fecha. Sempre que tem uma flor, eu estou em X (outra cidade) na casa da minha mãe, eu nunca consigo ver a minha flor aberta. Mas esta semana eu estava em casa aqui em SP e consegui ver minha flor. Esse gatinho é o Chiquinho, nosso gatinho que mora com a minha mãe".

No terceiro desenho, com vários sacos de lixo, materiais de limpeza, vassouras, rodo e uma janela com uma planta e um gatinho, a paciente expressa seus pensamentos, sentimentos e ações. As cores são discretas, a organização espacial é bem simétrica, a ausência da cinestesia é reforçada pelos objetos de limpeza encostados na parede e pelo gato que olha através da janela. Aparece a possibilidade de ver algo bom que nunca foi possível antes: o desabrochar da flor. 
A presença do mecanismo de corte assume um papel importante e eficaz na organização desse desenho. Os sacos de lixo bem fechados, atados e cheios, sinalizam que nada transbordou ou vazou, delimitando muito bem a fronteira do que está dentro do saco de lixo e que não serve mais, por isso pode ser descartado. A organização espacial e temporal é nítida e sentida imediatamente pela paciente que finaliza seu registro verbal de forma agradável e afetiva, referindo-se à flor e ao gatinho Chiquinho.

Há uma união de aspectos relacionados à satisfação entre o que existe em sua casa (flor) e na casa de sua mãe (gato) incluídos na mesma imagem. A mãe aqui pode também apresentar aspectos bons.

Esse desenho mostra também suas intenções de organizar seu quarto, tal como Prinzhorn (1922/1984) se refere à tendência a ordenar (pulsão de ordenação). Ela mora sozinha e por vezes conta no grupo que seu quarto o mantém desorganizado, que não consegue organizá-lo. É a organização espacial que tenta resolver, talvez na relação com sua mãe. São interessantes as noções de abertura e fechamento que expressa, ao estar próxima de sua mãe é o fechamento que se impõe, mas ao estar distante e só, a flor se abre! É justamente essa vivência da distância espacial que permite a ela rever sua vida, se discriminar de sua mãe.

\section{Desenho com pasta, escova de dente fio dental e um presente:}

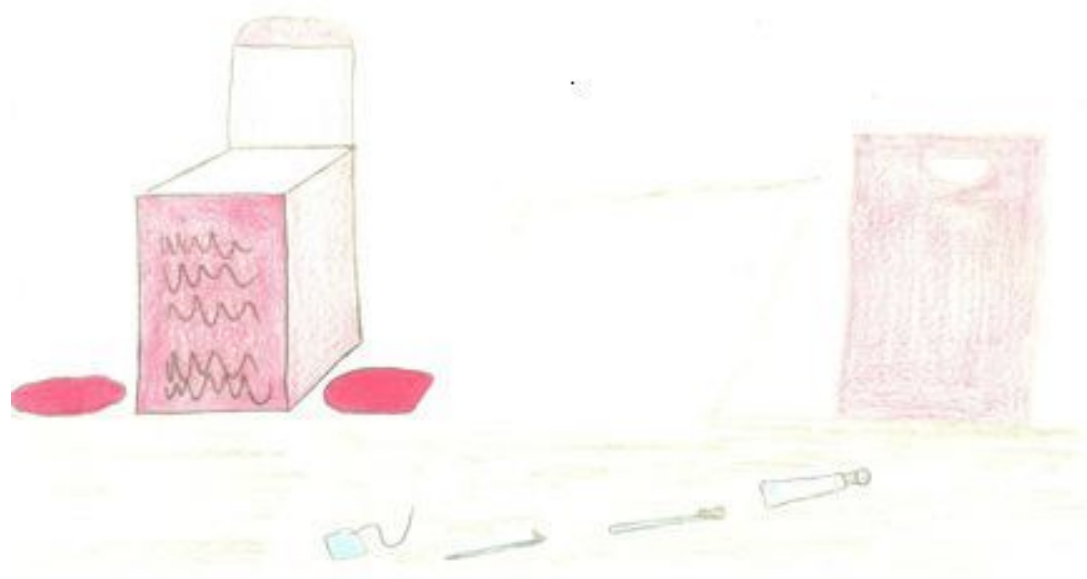

"Bem, eu morro de medo de ir ao dentista. Quando eu tinha 10 anos, eu ia ao dentista sem medo, mas naquele dia eu falei para a minha mãe que eu não queria ir. Quando cheguei lá, não conseguia deixar o dentista tratar os meus dentes. Minha mãe 
me levou ao banheiro, me deu uma surra, até que o dentista interferiu e disse que ela não deveria fazer isso, que seria pior. Desde esse dia então eu comecei a ter pavor de ir ao dentista. Meus dentes pioraram, e aos 13 anos, tive de ser internada no Hospital das Clínicas, tomar uma anestesia geral e eles arrancaram vários dos meus dentes, pois não tinha muito mais a ser feito. Desde então uso prótese dentária. Mas nesta semana eu estava na casa da minha mãe com a minha filha, e ela me incentivou para que eu fosse ao dentista. Eu tentei ir, falei ao dentista que eu estava com muito medo, contei a minha história, fiz o tratamento e no fim, ele me deu um presente - uma caixa de sabonetes cor de rosa, e me disse: "Parabéns, você conseguiu! Aliás, eu sabia desde o início que você iria conseguir!".

No quarto desenho, com a pasta, escova de dente, fio dental e uma caixa de presente, a paciente mescla uma lembrança positiva e vivida no presente com uma evocação desagradável do passado. A paciente tenta eliminar o desconforto do passado, aproximando as imagens (caixa de sabonete) a uma nova experiência vivida de conquista e superação.

A produção desse desenho mostra a necessidade de confiar em alguém. Dois grandes medos aparecem, um de ir ao dentista e o outro, da violência sofrida pela mãe. Precisou ser anestesiada para cuidar dos dentes, para não sentir dor. Anos depois, nos conta que o dentista foi cuidadoso com ela, apoiando-a e reconhecendo seu enfrentamento.

\section{Desenho onde tem uma cama e uma mulher dando a luz a um bebê...}

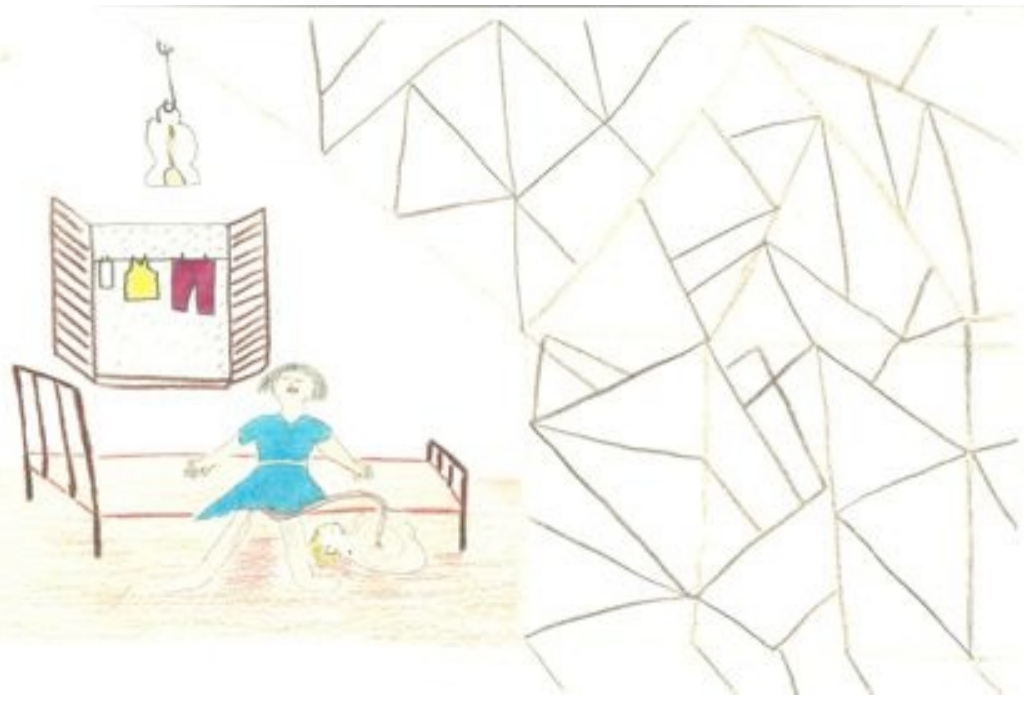

"Eu desenhei a minha mãe e eu. Eu nasci em casa. Minha mãe me contou que ela estava sozinha em casa quando eu nasci. Eu fiquei no chão por muito tempo, até que 
apareceu alguém para ver por que minha mãe não tinha ido trabalhar na roça naquele dia. Quando me viram no chão, foram chamar uma parteira rapidamente. Quando ela chegou, cuidou de mim e da minha mãe. Tinham roupas no varal, ia começar a chover e ai minha mãe se levantou e foi tirar a roupa do varal".

Nesse desenho, onde tem uma cama e uma mulher dando a luz a um bebê, a imagem é carregada na intensidade das cores e a presença de traços abstratos que se ligam a imagem sem lógica ou razão plausível. O tempo passado e o presente se confundem, o mecanismo de corte e ligação alternam-se e a paciente sente um intenso desconforto interno. O sentimento de desamparo, solidão e falta de continência marcam a imagem do nascimento. A mãe é capaz de pensar na roupa que irá molhar caso chova, mas não no bebê que acabou de nascer. $\mathrm{O}$ cuidado fica delegado à outra pessoa, a parteira, que se ocupa concretamente da tarefa. $\mathrm{O}$ afeto que não é integrado ao momento pode ser representado pelo desenho abstrato marcado pelo corte.

\section{Desenho de um banheiro, uma mulher e uma criança:}

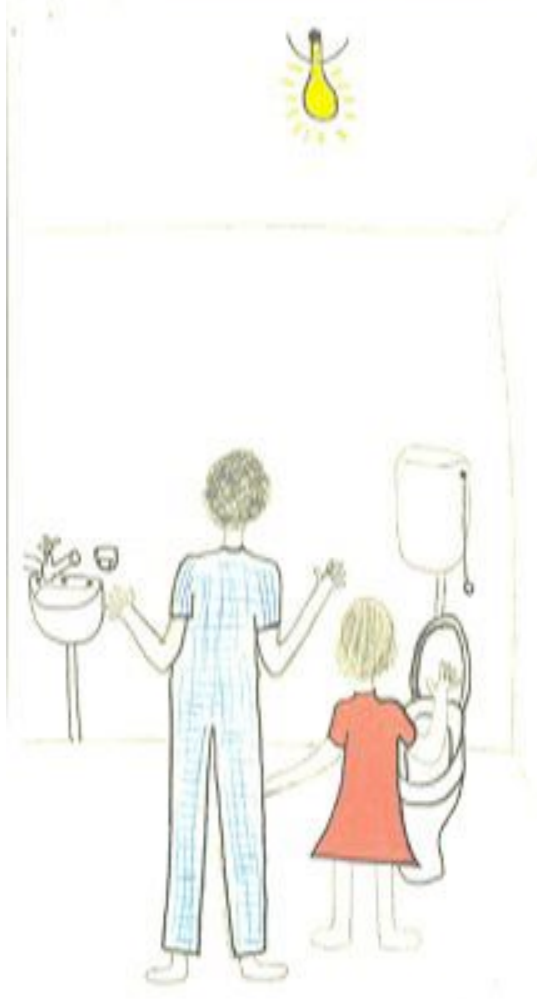

"Nesse desenho fiz eu e minha filha. Quando ela era pequena e ela fazia o número 2, dávamos tchau para o cocô, juntas...". 
$\mathrm{Na}$ tentativa de eliminar o desconforto gerado no quinto desenho, a paciente tenta anular o impacto atordoante da imagem de seu nascimento e faz o desenho de um banheiro, uma mulher e uma criança, que serve como um alívio e uma possibilidade de fazer algo junto com a filha mudando a história, em que a criança não se vê mais sozinha diante de algo importante, o que dá fôlego a paciente e leva a uma estabilização e recuperação do perdido. Nesse desenho a paciente aproxima a imagem da sua própria experiência de ser mãe. Observa-se, portanto, que o registro desagradável do dia do seu nascimento é substituído pelo registro agradável dela enquanto mãe, que acompanha, se ocupa e cuida de sua filha. Aqui observamos a manifestação do mecanismo de compensação fenomenológica para dar conta de experiências difíceis.

\section{Desenho de um casal com uma criança e uma casa:}

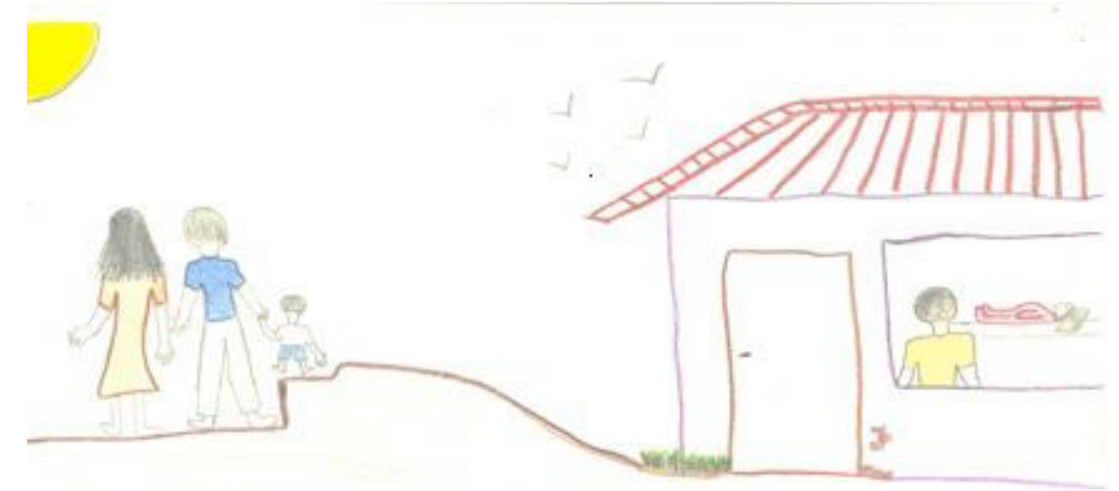

"Eu quis retratar o seguinte: Foi quando o meu pai foi embora com a melhor amiga da minha mãe e levou o meu irmão, que a minha mãe amava demais. Na casa ficamos minha mãe com 23 anos de idade e eu com apenas um mês de vida".

O último desenho dessa série, um casal com uma criança e uma casa, ilustra a cinestesia que se alterna com o estático e o imóvel. O movimento da família que se distância pelo caminho a fora se contrapõe com mãe e filha que ficam paradas e isoladas na casa. A filha deitada na cama representa a sua impotência diante do fato. $\mathrm{O}$ sentimento de abandono e rejeição também estão presentes no desenho.

A sequência dos desenhos quatro, cinco, seis e sete, revela a dificuldade de expressão emocional que é substituída por ideias ligadas às experiências 
corporais. A necessidade vivenciada de refugiar-se em experiências da infância funciona como uma primeira tomada de consciência sobre o processo de adoecimento da paciente. Para ela, compreender e reviver, por meio dos desenhos, os valores emocionais externos que perturbam seu equilíbrio interno é o inicio do processo de apropriação de seu estado de saúde atual.

\section{Desenho de uma montanha, uma corda e uma pessoa:}

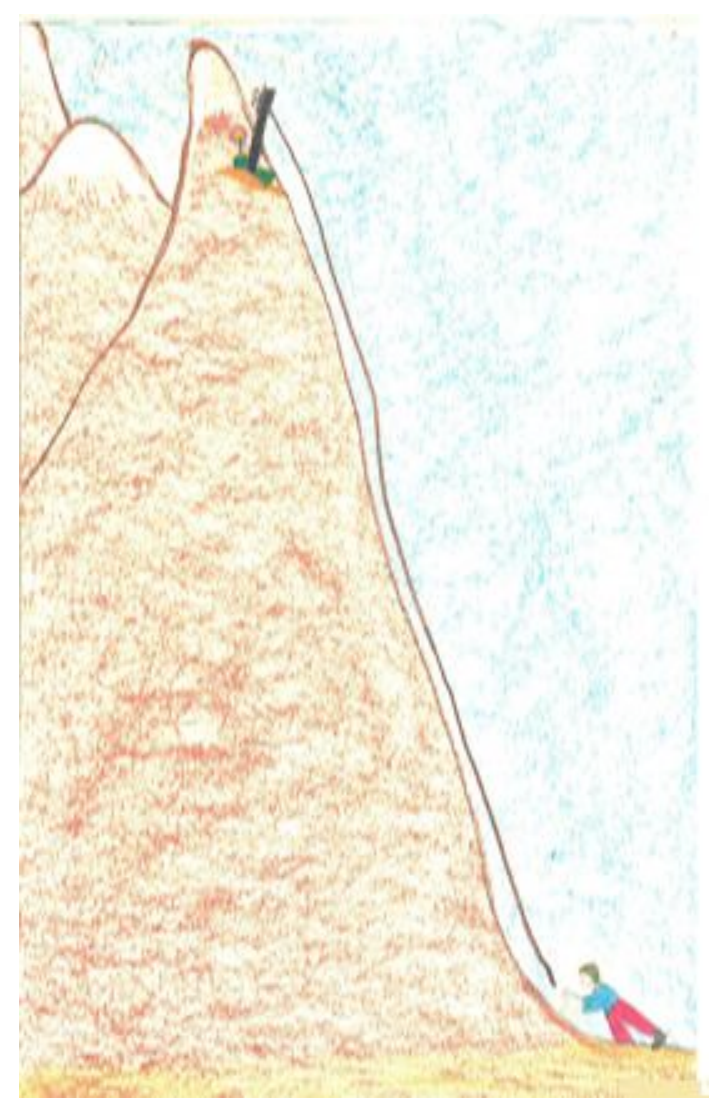

"Bem, essa montanha é a vida. Essa pessoa aí em baixo sou eu e essa corda é você, Y (terapeuta). Você é muito importante para mim. Com você, eu me sinto segura".

Ao completar três anos de atendimento, a paciente teve que se ausentar por um mês do Ateliê de Desenho, pois havia sido contratada em um novo emprego. Descontente com sua atividade nova, ela pede demissão. Ao retornar ao grupo, desenha os mesmos traços deste, no entanto, ela - a personagem que segura a corda - está a meio caminho desse morro e verbaliza a ajuda e apoio que sente nesse momento. A corda ou o terapeuta é a representação da ligação 
necessária entre o peso de seu sofrimento, que precisa ser carregado para poder atravessar um grande obstáculo e poder olhar e seguir seu caminho.

\section{Desenho de um ramo de planta, com um casulo, uma lagarta e uma borboleta:}

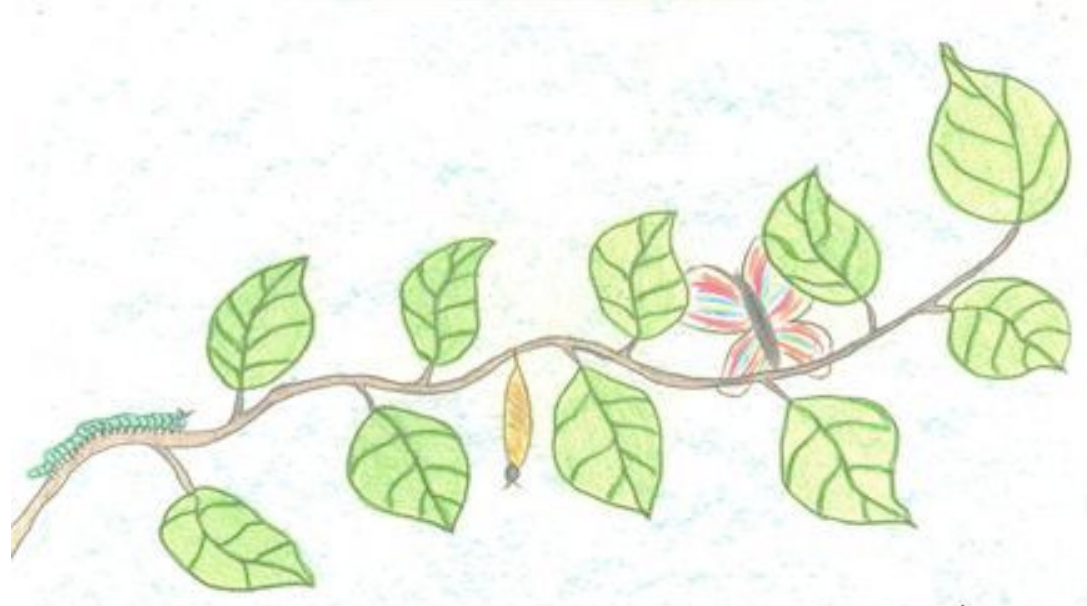

"Nesta semana, um colega nosso de trabalho, faleceu. O Sr. J. era muito querido e companheiro de todos. Ele era o nosso representante no sindicato dos funcionários, era prestativo e sempre tinha palavras de incentivo para todos. Todos nós e os professores ficamos muito tristes. Ele foi fazer um exame no hospital, para ver se estava com câncer ou não, e após o exame, sem antes saber o resultado, começou a passar mal e teve uma parada cardíaca. Esse desenho significa a vida, as fases da vida e é uma homenagem minha para ele".

Nos desenhos 8 e 9, o concreto e o sensorial são mais suavizados e o pensamento abstrato aparece com mais força.

No desenho de uma montanha, uma corda e uma pessoa, o mecanismo de ligação é bem nítido e funciona de forma adaptada e conectada com a experiência da realidade. A cinestesia e a presença das cores trazem uma harmonia na estética do desenho. A paciente compreende a sua fragilidade psíquica e ao mesmo tempo demonstra as forças internas ativadas e que lutam contra a fragilidade estrutural.

No último desenho, um ramo de planta, com um casulo, uma lagarta e uma borboleta, a paciente representa o processo de transformação, também carregado de cinestesia e sensorialidade. O seu discurso é associado com a evolução da vida que pode ser traduzido como a evolução de seu tratamento. 


\section{Considerações finais}

A sequência dos desenhos é um dado bastante significativo pra compreender a personalidade da paciente que lentamente se conecta com a sua própria história, existência e experiência vivida.

Nos desenhos, quatro, cinco, seis e sete, observam-se associações da infância e da relação mãe-filha com intervalos e uma lógica peculiar de um registro para outro. O desconforto mobilizado por lembranças do passado é substituído por imagens e percepções mais concretas e sensoriais.

Dessa forma, a sequência dos desenhos demonstra uma evolução gradual que pode ser percebida na qualidade e organização dos desenhos e do discurso associado a cada desenho. Assim, a análise fenômeno-estrutural é um método de investigação que compreende o modo como a pessoa se expressa, seja de forma verbal ou gráfica, revelando o valor da experiência, trazendo à tona a percepção subjetiva diante do sofrimento existente.

Como pudemos observar, os desenhos mostram as preocupações e os interesses com os detalhes, sendo realizados com ritmo lento, com cuidado e atenção. As cores são suaves e presentes, indicando como expressa seus afetos na atividade de desenho livre. Nos desenhos há pouca expressão de movimento, denotando uma racionalidade predominando sobre a sensorialidade. Esta existe e se expressa em forma de sofrimento e de desamparo, que foram diminuindo, ao mesmo tempo em que desenvolvia possibilidades associativas entre os acontecimentos depressivos e sua história, do que não se apropriava no início do tratamento.

Em suas verbalizações, a paciente relacionou suas vivências com as imagens, experimentando também a possibilidade de se colocar no lugar do outro, dirigindo-se a uma abertura em direção ao porvir, à alteridade e ao reconhecimento do outro. Por meio dos desenhos nos deparamos com surpresas ao longo desse processo, decorrentes de uma ação terapêutica, através de uma compreensão empática e de ações solidárias ao modo de ser do outro.

Por meio dos desenhos e das associações que os acompanham nos cuidados terapêuticos, a paciente gradativamente apropriou-se da possibilidade de reconhecer o outro e integrar suas experiências vividas, retomando aspectos de sua história passada, atual e suas expectativas futuras.

Por fim, essa investigação-clínica nos revela os seguintes achados: 
Os mecanismos de ligação e corte se encontram também nas vivências depressivas, não só nas epilépticas e esquizofrênicas, mas em qualquer estrutura humana. Observamos em seus desenhos, que a cada ruptura ou cisão, o mecanismo de ligação aparece, coesão apreendida pela análise qualitativa (Minkowska, 1956).

A análise da linguagem verbal, tanto quanto a observada no Rorschach por Minkowska (1956), pode ser apreciada na linguagem relacional diante da produção de desenhos, tal como Minkowski (1966) estudou minuciosamente nos discursos de seus pacientes.

No Ateliê de Pintura de Livre Expressão pudemos acompanhar a sucessão de imagens ao longo do tempo, como ocorre no método de Rorschach. Os desenhos são "atos espirituais" (Cassirer), bem como por meio deles acompanhamos a evolução estrutural (Helman, 1983). Toda estrutura tem movimento, não é estática como se entende no senso comum. Os desenhos mostram o campo do imaginário da paciente e na sua linguagem expressiva a fonte dos estudos fenômeno-estruturais (Helman, 1998). Desenhar livremente permitiu que a paciente ordenasse as coisas em seu estilo pessoal, conforme Prinzhorn (1922/1984) desenvolveu sobre a pulsão de ordenação.

Há um contato cada vez mais dinâmico com a realidade por parte da paciente. No início sentia depressão, hoje ela compreende o que alimentava esse estado, pois luta para manter uma relação mais dinâmica com a realidade, que agora lhe fornece uma condição mais vitalizada diante da vida (Minkowski, 1953).

No Ateliê é possível acompanhar o processo de criação (Oury, 1989) quando ele aparece, mas esse processo precisa se dirigir a alguém (Ternoy, 1997), pois tal energia tem suas raízes relacionadas à necessidade de expressão (Oury, 1989), a necessidade de comunicação (Prinzhorn, 1922/1984) ou a imagem como raiz da realidade (Bachelard, 1957/1998).

Os desenhos espontâneos mostram as raízes da vida afetiva (Minkowski, 1965) e a possibilidade de conhecer sua afetividade pelo esforço de compenetração e compreensão terapêuticas (Minkowski, 1999), bem como indicam o uso de cores adequadas, com tom afetivo de seus aspectos sensoriais e a falta de movimento e a precisão geométrica, seu tom racional (Minkowska, 1956; Helman, 1959).

A paciente dá sentido ao que faz, corroborando Ternoy (1999a) que afirma que ser é fazer e dar sentido ao que foi feito. $O$ traço nessa paciente representa importantes facetas de sua vida, não só suas imagens, mas aquilo que ela é (Picasso, 1937). 
Comprovamos, conforme Barthélémy (2009), que a psicopatologia guarda uma coesão e coerência interna surpreendentes ao mesmo tempo em que todo ser humano têm capacidades inatas de adaptação. Por meio do estudo de caso aprofundado, o foco clínico-investigativo vai de encontro à essência da pessoa e de como ela vive o sofrimento que a afeta (Barthélémy, 1997).

Pudemos verificar uma sensibilidade ao mundo dos afetos que vai sendo integrada por meio dos desenhos e do compartilhar as experiências em grupo. Dessa forma, a inter-relação por meio da interlocução é central no método fenômeno-estrutural onde as evoluções são compreendidas pelo acesso à subjetividade compartilhada e a paciente pode seguir seu caminho para vir a ser quando alguém apreende aquele que se expressa (Ternoy, 1987).

\section{Referências bibliográficas:}

Amparo, D. M. (2002). A simbolização na esquizofrenia: um estudo fenômenoestrutural com o método de Rorschach. Tese de Doutorado. Universidade de Brasília: Brasília.

(2004). A visão em imagens e o mundo de formas na esquizofrenia. In Cicero Emidio Vaz \& Rodrigo Linck Graeff (Orgs.). Técnicas projetivas: produtividade em Pesquisa 1 (pp. 279-283). Porto Alegre: Casa do Psicólogo: SBRo, v. 1.

(2010). A segmentação da imagem e o mecanismo da cisão na esquizofrenia. In: Anna Elisa Villemor-Amaral \& Latife Yazigi (Orgs.). Psicopatologia fenômeno-estrutural (pp. 29-81). São Paulo: Casa do Psicólogo.

Amparo, D. M. \& Antúnez, A. E. A (2008). Abordagem fenômeno-estrutural e o método de Rorschach. In Villemor-Amaral \& A. E. Werlang, B. S.. (Orgs.). Atualizações em métodos projetivos para avaliação psicológica (pp. 55-58). São Paulo: Casa do psicólogo, v. 1.

Antúnez, A. E. A \& Santoantonio, J. (2008). Análise fenômeno-estrutural e o estudo de casos. Boletim Academia Paulista de Psicologia. Ano XXVIII. Ano 01/08, 53-71.

Antúnez, A. E. A \& Santoantonio, J. (2010). Análise fenômeno-estrutural de uma pessoa com depressão ao longo de dois anos de acompanhamento psicológico. In: Anna Elisa Villemor-Amaral \& Latife Yazigi (Orgs.). Psicopatologia FenômenoEstrutural (pp. 119-143). São Paulo: Casa do Psicólogo. 
Bachelard, G. (1998). La poétique de l' espace. Paris: Presses Universitaires de France. (Trabalho original publicado em 1957).

Barthélémy, J. M. (1997). A análise da linguagem no Rorschach segundo o método fenômeno-estrutural. Anais - I Congresso da Sociedade Brasileira de Rorschach e outros Métodos Projetivos e I Congrès de la Société Internationale de Psychopathologie Phénoméno-structurale. Ribeirão Preto, 99-104. (trabalho completo)

(2006). Importance et extension de l'approche qualitative dans la méthode phenóméno-structurale em psychopathologie. Bull. Soc. Sci. Méd. 2, 249-264.

(2009). Comunicação pessoal. Curso de pós-graduação A psicopatologia fenômeno-estrutural: aproximação teórica, clínica, psicopatológica e terapêutica; Programa de Pós-graduação do Departamento de Psicologia Clínica do Instituto de Psicologia da Universidade de São Paulo. http://www.iptv.usp.br:80/portal/Id.do?instance=0\&id=usp1FDbPYT19BXm QUU0L80I7MTaNSgrLjNpwnzVrrqeBWw.\&type=video

Delaunay, P. (1975). Image et langage dans le rêve éveillé dirigé, analyse phénoméno structurale. Tese de doutorado. Universidade de Lille-III. Lille. França.

Ferraz, M. H. C de Toledo (1998). Arte e loucura - limites do imprevisível. São Paulo: Lemos Editorial.

Helman, Z. (1959b). Rorschach eléctroencéphalo gramme chez l'enfant épileptique. Paris: PUF.

. (1983). La vision en images dans la psychopathologie structurale. Bulletin de Psychologie, v. XXXVI, n. 362, 811-819.

. (1984). Délire et vision en images. Psychopathologie structurale, vol. 4, p. 9-22. Toulouse : Érès

(1997). Psicopatologia fenômeno-estrutural e método de Rorschach: a evolução de uma corrente, seus desenvolvimentos atuais. Anais - I Congresso da Sociedade Brasileira de Rorschach e outros Métodos Projetivos e I Congrès de La Société Internationale de Psychopathologie Phénoméno-Structurale. Ribeirão Preto, 279-290. (Trabalho completo).

. (1998). Psychopathologie phénoméno-structurale et méthode de Rorschach: l'évolution d'un courant, ses développements actuels. Bulletin de Psychologie, v. 51, n. 434, 93-99. 
Jacquemin, A. (1998) Psychopathologie phénoméno-structurale et Rorschach : la richesse dans la recontre. Bulletin de Psychologie, 51 (434), 101-103.

Minkowska, F. (1949). De Van Gogh et Seurat aux dessins d'enfants. Paris: Presses du Temps Présent. In: Yazigi, L. (2002) Two styles of mental functioning and literary language: a phenomenological psychological reading of A. Machado and $C$. Cavafy. A tribute to Zena Helman. Psic.: Teor. e Pesq., Brasília, v. 18, n. 3.

(1978). Le Rorschach. Paris: Desclée de Brouwer. (Trabalho original publicado em 1956)

Minkowski, E. (1953). La schizophrénie. Psychopathologie des schizoïdes et de schizophrènes. 2ème éd. France: Desclée de Brouwer (Trabalho original publicado em 1927).

. (1965). Recueil d'articles 1923-1965. In: Eugène Minkowski et Zéna Helman (Orgs.) Cahiers du groupe Françoise Minkowska, n.15.

. (1966). Traité de psychopathologie. Paris: PUF.

(1999). Traité de psychopathologie. Paris: Collection Les Empêcheurs de penser en rond. (Trabalho original publicado em 1966).

Oury, J. (1989). Création et schizophrénie. Paris: Galilée.

Picasso, P. (1937-1945). Anos de guerra [Exposição]. São Paulo: Museu de Arte de São Paulo Assis Chateaubriand; 21/09 a 15/11 - 1999.

Prinzhorn, H. (1984). Expressions de la folie dessins, peintures sculptures d'asile. Les fondements psychologiques de la "Gestaltung" plastique. Paris: Gallimard. (Trabalho original publicado em 1922).

Rorschach, H. (1967). Psicodiagnóstico. Tradução Ane Sophie Villemor Amaral. Rio de Janeiro: Mestre Jou. (Originalmente publicado em 1921)

Samba, D. (1981). Rorschach de délirants étudiés chez des sujets transplantés africains, analyse phénoméno-structurale. Lille, 1981. Thèse. Doctorat en Psychologie. Université de Lille III.

Santoantonio, J. \& Antúnez, A. E. A. (2002). Atelier de pintura de livre expressão em hospital dia psiquiátrico [Versão Eletrônica]. Inter-Ação.com.

Recuperado em 10 maio 2008, de http://www.ciec.org.br/Artigos/Revista_1/jacqueline.pdf 
Santoantonio, J. \& Antúnez, A. E. A. (2010). Ateliê de desenho e Rorschach: estudo fenômeno-estrutural. Paideia. jan.-abr., Vol. 20, n.. 45, 117-122.

Ternoy, M. (1987). L'espace pictural de groupe. Rorschach et psychopathologie phénoméno-structurale. Expression et psychopathologie. In Colloque Octobre. France: Recueil no. 3; pp.12-20.

(1997). Rorschach, rêve éveillé et expression grapho-picturale dans l'étude phénoméno-structurale des hallucinations [Thèse]. France: Université de Lille III.

(1998). Une caractéristique spécifique de la vision en images chez l'halluciné: le détaillage. Bulletin de psychologie, tome 51(2)/434/mars- avril, 135141.

(1999a). A obra de Augustin Lesage: pintor mediúnico - a criação de uma existência entre a invenção e repetição. Estudo Psicopatológico. In Spinelli J et al. Criatividade - uma busca interdisciplinar (pp. 30-40). São Paulo: UNESP.

(1999b). Rorschach, psicosis y alucinaciones: enfoque fenomenoestructural. Psicodiagnosticar /Volumen IX - Año XI, pp. 34-46

(2006). La peinture, c'est de l'intimité qu'on partage. Revue francaise de psychiatrie et de psychologie médicale. Vol. 10, n·99, 11-15. Editions MF, Paris.

Van Gogh, V. (2010). Cartas a Théo. Tradução de Pierre Ruprecht. Porto Alegre: L\&PM Pocket. 416 p.

Villemor-Amaral, A. E \& Yazigi, L. (orgs.) (2010). Psicopatologia fenômenoestrutural. São Paulo: Casa do Psicológo.

Wallon, H. (1978). De l'acte à la pensée. Paris: Flammarion. . (1987). Les origines du caractère chez l'enfant. Paris : P.U.F.

Wawrzyniak, M. (1994). Psychopathologie de la Schizophrénie et psychopathologie de adolescence. Étude phénoméno- structurale. Tese de doutorado d' Etat. Universidade de Lille III. Lille. França.

- (1995, outubro). Psicopatologia da esquizofrenia e psicologia do adolescente : um fenômeno estrutural. Palestra proferida no I Encontro de Rorschach e outros Métodos Projetivos. Ribeirão Preto. 
. (1998). Introduction. Bulletin de psychologie, tome 51, n. 2, 91-92.

mars-avril.

- (2000). Dissociation et temps vécu dans les psychoses débutante à adolescence. Approche phénoméno-structurale. L'Evolution Psychiatrique, n. 65, 37-54.

Yazigi, L. (2002). Two styles of mental functioning and literary language: a phenomenological psychological reading of A. Machado and C. Cavafy. A tribute to Zena Helman. Psic.: Teor. e Pesq., Brasília, v. 18, n. 3. 